\title{
APLIKASI PENGINDERAN JAUH \& SIG UNTUK PENETAPAN TINGKAT KEMAMPUAN PENGGUNAAN LAHAN (KPL) (Studi Kasus di DAS Nawagaon Maskara, Saharanpur-India)
}

\author{
Beny Harjadi \\ Balai Penelitian Kehutanan Solo \\ Jalan Ahmad Yani Pabelan, Po.Box.295, Surakarta. Jawa Tengah, \\ Telp/Fax : 0271-716709, 715969 \\ E-mail: bpksolo@indo.net.id
}

\begin{abstract}
The land that was increasingly crowded resulting from the inhabitants's speeding-up pressure, required the utilisation of the land to be as efficient and as effectively as possible. For this matter must be known by the LUC (Land Use Capability) class respectively the unit of the land management, so as to be known as early as possible the obstacle factor from the land and could be done by the utilisation of the land as optimally as possible. The implementation of the LUC determination must be carried out a stage for the sake of a stage by counting LUC respectively the main factor, so as to be received by LUC-Soil, LUC-Erosion, and LUC-Slope. The next one of the three of this LUC were just counted by the value of the maximum to appoint LUC Final. LUC-Slope by being based on the Wischmeier and Smith (1978), LUC-Erosion was counted by using the quantitative MMF erosion formula (Morgan, Morgan, and Finney), and LUC-Soil by gathering the physical data the field took the form of the texture data of the land, drainage, solum and the perrentage of the rock in the surface. LUC-Erosion and LUC-Soil were received by 5 LUC classes (I, II, III, IV, IV, and VI), whereas LUC-Slope was received by 7 LUC classes all of them except the V. LUC I class until IV were recommended for the agricultural crop and LUC V until VIII for the forestry crop. From 11 of Sub Watershed LUC VIII was expanded 107.54 ha to Sub Watershed Sarbar Rao and narrowest to Sub Watershed Maskara Rao $(0.12$ ha). On the other hand for LUC II was expanded to Sub Watershed Nawagaon Rao (1136.8 ha) and narrowest (1.51 ha) to Sub Watershed Shakumbari Rao. The location of the research in Sub Watershed Nawagaon Rao Mascara the Sabaranpur city, India, with the location goegrafis from 30 $09^{\prime} 00^{\prime \prime} \mathrm{N}-30^{\circ} 21^{\prime} 00^{\prime \prime} \mathrm{N}$ and longitude $77^{\circ} 34^{\prime}$ $00^{\prime \prime} \mathrm{E}-77^{\circ} 51^{\prime} O 0^{\prime \prime} \mathrm{E}$, widely the Watershed whole $205.94 \mathrm{~km} 2$ or $20594.49 \mathrm{ha}$. The analysis of the image satelit with IRS (Indian Remote Sensing) LISS IV in January 2005, the anabsis of three dimensions with DEM SRTM, and the map of the topography of the sheet $53 \mathrm{~F} / 11,53 \mathrm{~F} / 12,53 \mathrm{~F} / 15$ and $53 \mathrm{~F} / 16$. The aim of the research of determining the LUC class by counting each one of LUC-Soil, LUC-Erosion, and LUC-Slope. The use of the land in the Nawragaon Maskara Rao Watershed in part: Wheat super $(969,26)$, normal Wheat $(2753.7$ ha), the Orchard $(2103.2$ ha), the Forest was rather close (3930.5 ha), the Forest was open (3352.1 ha), Scrub (168.62 ha), Brush rocky (658.56 ha), and Open land (1814.8 ha). Was based on results of this research recomendation for LUC VIII was only for the protected forest that might not be touched or produced.
\end{abstract}

Key words : LUC, Remote sensing, GIS, Nawagaon-Maskara Watershed, India

\section{PENDAHULUAN}

Pertambahan penduduk akan mengakibatkan sebagian fungsi tanaman penghijauan atau pertanian khususnya pada daerah persawahan akan beralih fungsi menjadi lahan tempat hunian, akibatnya lahan pertanian atau penghijaun tanaman hutan dari hari ke hari semakin menyempit. Oleh karena itu perlu dilakukan pemanfaatan lahan seoptimal miungkin. Untuk keperluan tersebut setiap lahan perlu dilakukan analisis tingkat kemampuan penggunaan lahan (KPL) untuk mengetahui potensi optimum dari suatu lahan.

Di dalam analisis kemampuan penggunaan lahan pada suatu DAS dengan mengumpulkan beberapa parameter tetap dan 
parameter berubah terdapat beberapa kendala antara lain; waktu yang lama dan biaya yang tinggi serta tenaga survai yang memadai dari berbagai disiplin ilmu; mengingat parameter yang dikumpulkan bervariasi, meliputi parameter tetap (bentuk lahan, jenis batuan, jenis tanah dan kemiringan lereng), serta paremeter berubah (erosi, teras dan penggunaan dan penutupan lahan).

Mengingat perlu dilakukan analisis penetapan tingkat kemampuan penggunaan lahan namun mahal dalam pelaksanaan survai, maka diperlukan alat bantu yang lebih murah dan lebih akurat, yaitu dengan memanfaatkan teknik PJ melalui analisis citra satelit, peta tiga dimensi DEM SRTM, dan peta erosi.

Berkenaan permasalahan tersebut di atas maka perlu dilakukan analisis KPL dengan menggunakan 3 paremeter utama yaitu jenis tanah, kemiringan lereng dan erosi. Tujuan penelitian ini adalah :

1. menetapkan KPL TANAH dari parameter karakteristik tanah dengan citra satelit

2. menetapkan KPL LERENG berdasarkan peta kelas lereng dengan DEM SRTM

3. menetapkan KPL EROSI berdasarkan hasil perhitungan MMF

4. menetapkan KPL final dari maksimum ketiga KPL (tanah, lereng, dan erosi).

DAS Nawagaon Maskara Rao, kota Saharanpur India, propinsi Uttar Pradesh dan masuk wilayah India Utara, kurang lebih $150 \mathrm{~km}$ ke arah timur laut dari ibukota India (New Delhi). Secara fisik bagian utara dan timur laut dikelilingi oleh perbukitan Shivalik dan terpisah dengan wilayah Dehradun yang termasuk propinsi Uttranchal. Sungai Yamuna dari batas sebelah barat, yang terpisah dari wilayah Karnal dan Yamunagar, propinsi Haryana. Sebelah timur dibatasi wilayah Haridwar yang merupakan wilayah Saharanpur dan sebelah selatan dibatasi oleh wilayah Muzafarnagar.

Secara geografis daerah penelitian terletak antara $30^{\circ} 09^{\prime} 00^{\prime \prime}-30^{\circ} 21^{\prime} 00^{\prime \prime}$ LU dan $77^{\circ} 34^{\prime} 00^{\prime \prime}-77^{\circ} 51^{\prime} 00^{\prime \prime}$ BT, dengan luas keseluruhan DAS 205,94 km atau 20.594,49 ha. Daerah penelitian DAS Nawagaon Maskara Rao dibatasi dengan menggunakan peta topografi skala 1 : 50.000 dengan nomer peta $53 \mathrm{~F} / 11,53 \mathrm{~F} /$ 12, $53 \mathrm{~F} / 15$ dan $53 \mathrm{~F} / 16$. Lokasi penelitian dapat dilihat pada Gambar 1.

\section{METODE PENELITIAN}

\section{Ruang Lingkup Kegiatan}

Analisis KPL Final ditetapkan dengan terlebih dahulu menghitung masingmasing KPL yaitu : KPL Tanah, KPL Lereng dan KPL Erosi. KPL Tanah dihitung berdasarkan hasil pengumpulan data di lapangan maupun analisis citra satelit dengan mengggunakan citra IRS (Indian remote Sensing) LISS IV. KPL Lereng dihitung dari data digital DEM (Digital Elevatioan Model) SRTM untuk analisis tiga dimensi dengan menggunakan rumus :

Lereng $(\%)=$ Slope Percent $=100 *$ HYP (Dx, Dy)/Ukuran Piksel Lereng $\left(^{0}\right)=$ Slope Degree $=\operatorname{Rad}$ Deg [ATAN (Slope Percent/100)]

KPL erosi dihitung dari analisis citra satelit dari beberapa data fisik lapangan, dengan menggunakan rumus MMF (Morgan. Morgan, and Finney, 1984), yaitu :

Fase Air :
$\mathrm{E}=\mathbf{R} *(11.9+8.7 * \log \mathrm{I})$
Dimana :
E : energi kinetik hujan $\left(j / \mathrm{m}^{2}\right)$
$\mathrm{R}$ : hujan tahunan (mm) 


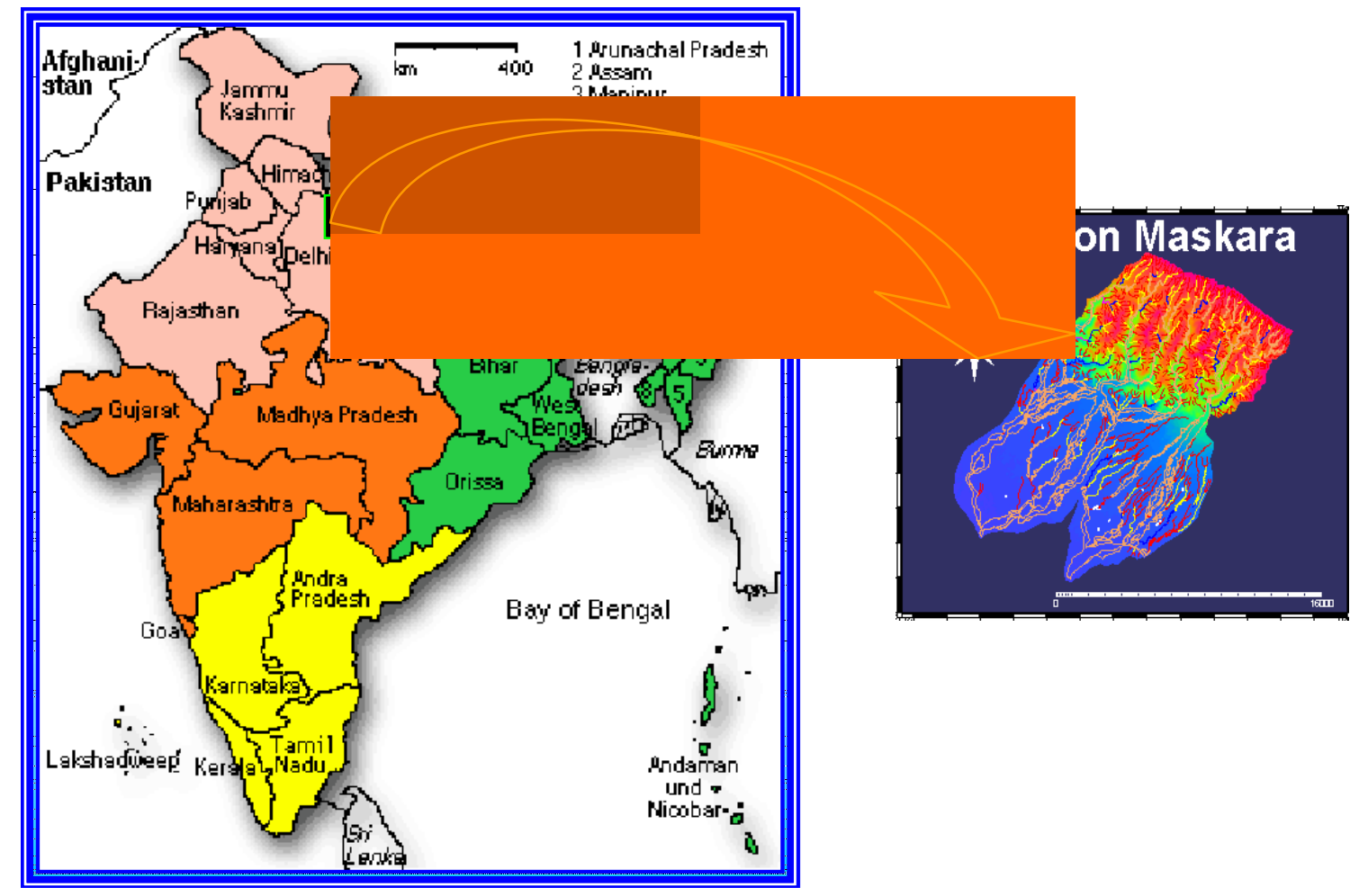

Gambar 1. Lokasi Penelitian di DAS Nawagaon Maskara Rao, Saharanpur, Uttar Pradesh, India Utara.

I : intensitas hujan yang menyebabkan erosi ( $\mathrm{mm} / \mathrm{jam})$

Fase Sedimen:

$\mathrm{F}=\mathrm{K} *\left[\mathrm{E} * \mathrm{e}^{(-0.05 * \mathrm{~A})}\right] * 10^{-3}$

Dimana :

F : kecepatan pemecahan tanah akibat hujan yang jatuh $(\mathrm{kh} / \mathrm{m} 2)$

$\mathrm{K}$ : index pemecahan tanah $(\mathrm{g} / \mathrm{j})$

E : energi kinetik hujan $(j / m 2)$

A : persentase hujan yang terintersepsi dan aliran batang.

\section{Bahan dan Alat Penelitian}

Data yang digunakan dalam penelitian ini meliputi : peta digital (DEM= Digital Elevation Model) SRTM, data digital satelit LISS IV dengan resolusi $5.8 \mathrm{~m}$ pada kolom/garis (path/row) 202/203 tertanggal 28 januari 2005, peta cetak citra satelit FCC (False Colour Composite), dan SRTM tiga dimensi Digital Elevation Model (DEM), lihat. Data tambahan yang diperlukan berupa peta topografi dari SOI (Survey of India $=$ Survei tanah seluruh India) no. 53 F/11, 53 F/12, $53 \mathrm{~F} / 15$ dan $53 \mathrm{~F} / 16$ skala $1: 50.000$. Data karakteristik dan laporan survai tanah diperoleh dari jurusan Pertanian dan Tanah, IIRS (Indian Institute Remote Sensing) Dehradun, India.

Kelengkapan data iklim diperoleh dari stasiun meteorology dari Muzzafarabad yang menyediakan data meteorologi, dalam bentuk data rerata hujan bulanan selama 16 tahun dari 1988 sampai 2004. 
Persiapan pembuatan batas DAS dan titik outlet (keluaran DAS), peta kontur, dan peta dasar menggunakan peta topografi dari SOI. Sedangkan untuk peta penggunaan lahan dan peta tanah dilakukan persiapan dengan data digital citra satelit LISS IV. Untuk pengumpulan data fisik lapangan diperlukan peralatan lapangan antara lain: Disc infiltrometer untuk mengukur kecepatan infiltrasi, ring sampel untuk pengambilan sampel tanah tak terganggu maupun sampel tanah terganggu.

\section{Rancangan Penelitian}

Metodologi penelitian meliputi : (a) persiapan lapangan : interpretasi data satelit untuk satuan tanah fisiografi dan penyiapan peta jaringan drainase pada studi area, (b). pelaksanaan lapangan dengan melakukan survai lapangan yang diawali dengan: pemilihan sampel lapangan untuk penutupan dan penggunaan lahan, pengamatan kecepatan infiltrasi, pengambilan sampel tanah dengan ring sampel dan tekstur tanah, pengamatan kenampakan besarnya erosi dan jenis erosi di lapangan, (c) setelah kegiatan lapangan: modifikasi koreksi hasil interpretasi dengan melakukan reinterpretasi ulang, menganalisis sampel tanah, analisis dan perhitungan perkiraan erosi dengan MMF, (d) penetapan KPL Final dengan memilih maksimum dari KPL Tanah, KPL Lereng, dan KPL Erosi.

\section{Pengumpulan dan Pengolahan Data}

Data yang dikumpulkan di lapangan sesuai keperluan untuk menetapkan kemampuan penggunaan lahan (KPL), antara lain pengamatan dan pengumpulan data : tekstur tanah, drainase, kedalaman tanah, dan persen batuan di permukaan, lereng dan beberapa faktor fisik lainnya. Sebagian data diperoleh dari hasil anslisis citra satelit dengan analisis komputerisasi dan dengan bantuan system informasi geografis (SIG).

\section{Analisis Data}

Dengan menggunakan data citra satelit IRS LISS IV dianalisis fisiografi tanah, dengan ditetapkan beberapa parameter sifat fisik tanah antara lain : tekstur, drainase, kedalaman tanah dan persen batuan di permukaan. Peta tiga dimensi dari SRTM DEM diperuntukkan bagi pemetaan kelas lereng (lihat Gambar 2). Parameter ketiga berupa erosi tanah dihitung dengan menggunakan rumus MMF (Morgan, Morgan, dan Finney).

Dari ketiga parameter KPL tanah dari peta Fisografi, KPL Lereng dari peta kemirngan lereng SRTM dan KPL erosi dari perhitungan peta erosi MMF, selanjutnya ditetapkan maksimum dari KPL tersebut sebagai KPL Final dengan rumus sebagai berikut :

\section{KPL Final = Maksimum (KPL Tanah, KPL Lereng, KPL Erosi)}

Dimana :

KPL Final =Kemampuan Penggunaan Laban Maksimum

KPL Tanah $=$ KPL berdasrkan analisis citra satelit untuk sifat fisik tanah

KPL Lereng $=$ KPL dianalisis dari peta tiga dimensi DEM SRTM

KPL Erosi $=$ KPL dari hasil perbitungan MMF (Morgan, Morgan, Finney)

HASIL PENELITIAN DAN PEMBAHASAN

\section{Kemampuan Penggunaan Lahan (KPL)}

Kemampuan Penggunaan Lahan (KPL) adalah salah satu cara untuk memperkirakan faktor pembatas lahan. Lahan diperkirakan menurut : (i) kecenderungan 


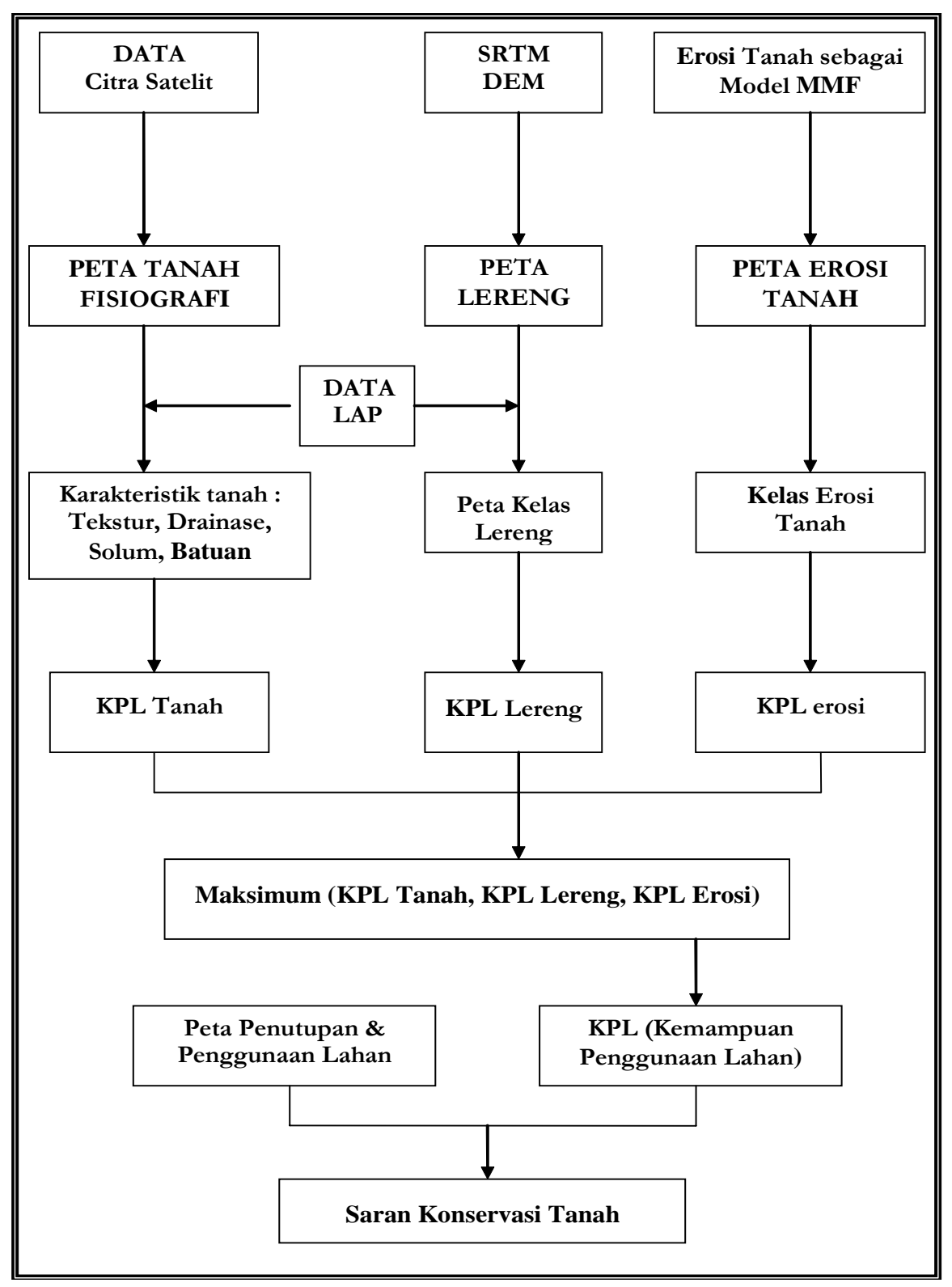

Gambar 2. Diagram Alur untuk Penetapan Kelas KPL

erosi - sebagai contoh lahan datar lawan lahan miring pada perbukitan, (ii) jenis tanah, (iii) kelembaban - sebagai contoh terlalu banyak atau terlalu sedikit drainase, (iv) iklim - termasuk waktu penyinaran matahari, tingkat hujan, angin, maksimum dan minimum temperatur (LAI, 1998). Ada delapan kelas KPL, dari I (lahan datar dengan tanah bagus dan sedikit faktor pembatas), sampai kelas VIII (lahan curam dengan beberapa faktor pembatas). Kelas I sampai IV adalah cocok untuk pertanian, dan kelas V sampai VIII tidak cocok untuk pertanian, tetapi lebih baik untuk tanaman kehutanan. Kelas VIII tidak sesuai untuk hutan produksi dan yang paling baik untuk semak belukar dan perlindungan waduk. 
Untuk menghitung KPL Final diperlukan tiga tahap kalkulasi, yaitu untuk KPL Tanah, KPL Lereng dan KPL erosi. Hasil dari tiga kalkulasi selanjutnya dipilih hasil yang maksimum untuk KPL dan ditetapkan menjadi KPL Final. Dengan tambahan informasi tentang jenis penutupan dan penggunaan lahan, maka dapat direkomendasikan saran untuk bangunan konservasi tanahnya (Lampiran 1). Penetapan KPL walaupun dapat dilakukan sepenuhnya dengan analisis citra satelit namun tetap diperlukan cheking lapangan untuk mencatat kondisi sebenarnya di lapangan. Hal tersebut karena dengan perubahan waktu pengambilan citra dengan kondisi lapangan maka beberapa parameter telah berubah terutama parameter berubah. Sedangkan untuk parameter tetap walaupun kondisi perubahan tidak berbeda dengan kenampakkan di citra, namun beberapa parameter fisik tetap diperlukan dari hasil lapangan. Faktor fisik yang harus dikumpulkan dari data lapangan tersebut antara lain : tekstur, drainase, dan kedalaman tanah.

Distribusi penyebaran masing-masing KPL Erosi, KPL Lereng dan KPL Tanah disajikan pada, yaitu informasi peta berkaitan dengan penyebaran kelas KPL di DAS Nawagaon Maskara Rao. Dari ketiga peta sebaran masing-masing kelas KPL tersebut selanjutnya dihitung dengan cara memilih maksimum dari setiap perhitungan untuk menetapkan KPL Final.

Dari KPL Tanah dan KPL Erosi diperoleh sama yaitu hanya 5 kelas KPL (I, II, III, IV, dan VI), sedangkan KPL Lereng diperoleh 7 kelas KPL (I, II, III, IV, VI, VII, dan VIII). Sehingga dari ketiga KPL (KPL Erosi, KPL Tanah dan KPL Lereng) tersebut diperoleh kelas KPL Final yang terdiri dari 6 kelas KPL (II, III, IV, VI, VII, dan VIII). Dari peta nampak berbeda ditribusi penye- baran kelas KPL dari ketiga cara perhitungan KPL. Jika dilihat dari erosi maka di daerah atas sebagian besar masih dapat dimasukkan kelas III karena erosi yang terjadi masuk dalam kategori tidak berat, tetapi jika dilihat dari faktor lereng maka sebagian besar kelas VI sampai VIII, karena lahan dalam kondisi yang curam sampai terjal.

Jika dibandingkan lebih jauh antara faktor erosi, lereng dengan faktor tanah maka akan beda juga hasil kelas KPL. Dimana KPL tanah lebih banyak memperhatikan faktorfaktor yang tidak dapat diprediksi langsung dari penginderaan jauh (citra satelit) karena diperlukan data lapangan dan analisis laboratorium. Dari faktor tanah yang lebih banyak menginformasikan Tingkat kesuburan tanah maka akan nampak bahwa pada lahan di daerah atas hampir didominasi lahan dengan kelas KPL VI, sebaliknya di daerah hilir dekat outlet didominasi kelas KPL I.

KPL akhir sebagai hasil dari ketiga perhitungan KPL mencerminkan beberapa faktor kondisi asli sifat fisik tanah (KPL Tanah), kondisi dari bentuk lahan dan kemiringan lereng (KPL Lereng), dan besarnya erosi yang terjadi akibat perpaduan kemiringan lereng dengan penutupan tanah (KPL Erosi). Hasil KPL akhir sudah mencakup beberapa faktor yang mempengaruhi kelas KPL. Dapat disimpulkan bahwa sebagian besar lahan memiliki KPL III (27.9 \%) pada lahan pertanian dan KPL VI pada lahan kehutanan $(22.7 \%)$.

\section{Rekomendasi Konservasi Tanah}

Perhitungan KPL untuk masingmasing 11 Sub DAS dapat dilihat pada Lampiran 2, dimana KPL VIII paling luas (107.54 ha) pada Sub DAS Sarbar Rao dan paling sempit (0.12 ha) pada Sub DAS Maskara Rao. Kelas KPL VIII hanya diperuntukkan untuk tanaman hutan rimba atau 
hutan primer yang tidak boleh ditebang atau diproduksi kayunya. Sehingga pemanfaatan hutan rimba hanya untuk penghasil non kayu misalnya lebah, satwa liar atau untuk wisata alam. Sebaliknya kelas terendah KPL II terluas pada Sub DAS Nawagaon Rao (1136.8 ha) dan paling sempit pada Sub DAS Shakumbari Rao (1.51 ha).

Penggunaan lahan di DAS Nawagaon Maskara Rao antara lain: Gandum super (969.26), Gandum biasa (2753.7 ha), Kebun buah (2103.2 ha), Hutan agak rapat (3930.5 ha), Hutan terbuka (3352.1 ha), Semak belukar (168.62 ha), Semak berbatu (658.56 ha), dan Bero (1814.8 ha). Masing-masing penggunaan lahan tersebut selengkapnya dapat dilihat pada Lampiran 3, yang menyajikan sekaligus dengan kelas KPL. Kelas KPL VIII terluas pada penggunaan lahan hutan agak rapat (193.63 ha) dan tersempit pada penggunaan lahan semak belukar (0.12 ha). Seangkan kelas KPL II terluas pada penggunaan lahan kebun buah (1123.7 ha) dan tersempit pada kondisi lahan bero (0.16 ha).

KPL dengan faktor lereng dari datar sampai terjal yaitu dari kelas II sampai VIII. Kelas KPL VIII yang paling luas pada lahan dengan kemiringan lereng terjal $(>50 \%)$ yaitu seluas 569.78 ha, dan tersempit pada kondisi lereng curam $(15-25 \%)$ yaitu seluas 0.01 ha. Sedangkan KPL lereng kelas II yang terluas pada lereng agak miring $(1-3 \%)$ yaitu seluas $1503.5 \mathrm{ha}$, dan tersempit pada lereng agak curam (10-15\%) seluas 0.1 ha. Daerah bawah atau lahan datar memiliki KPL II dan III sebaliknya pada daerah yang curam memiliki KPL VII dan VIII. Dimana kelas KPL IV terletak pada lahan pertanian, antara lain untuk gandum, tebu, dimana kelas lebih dari VI diperuntukkan untuk tanaman permanen berupa hutan (Gambar 3). Sehingga untuk KPL kelas I yang tidak mempunyai faktor penghambat sebaiknya dimaksimumkan untuk usaha tani intensif hortikul-

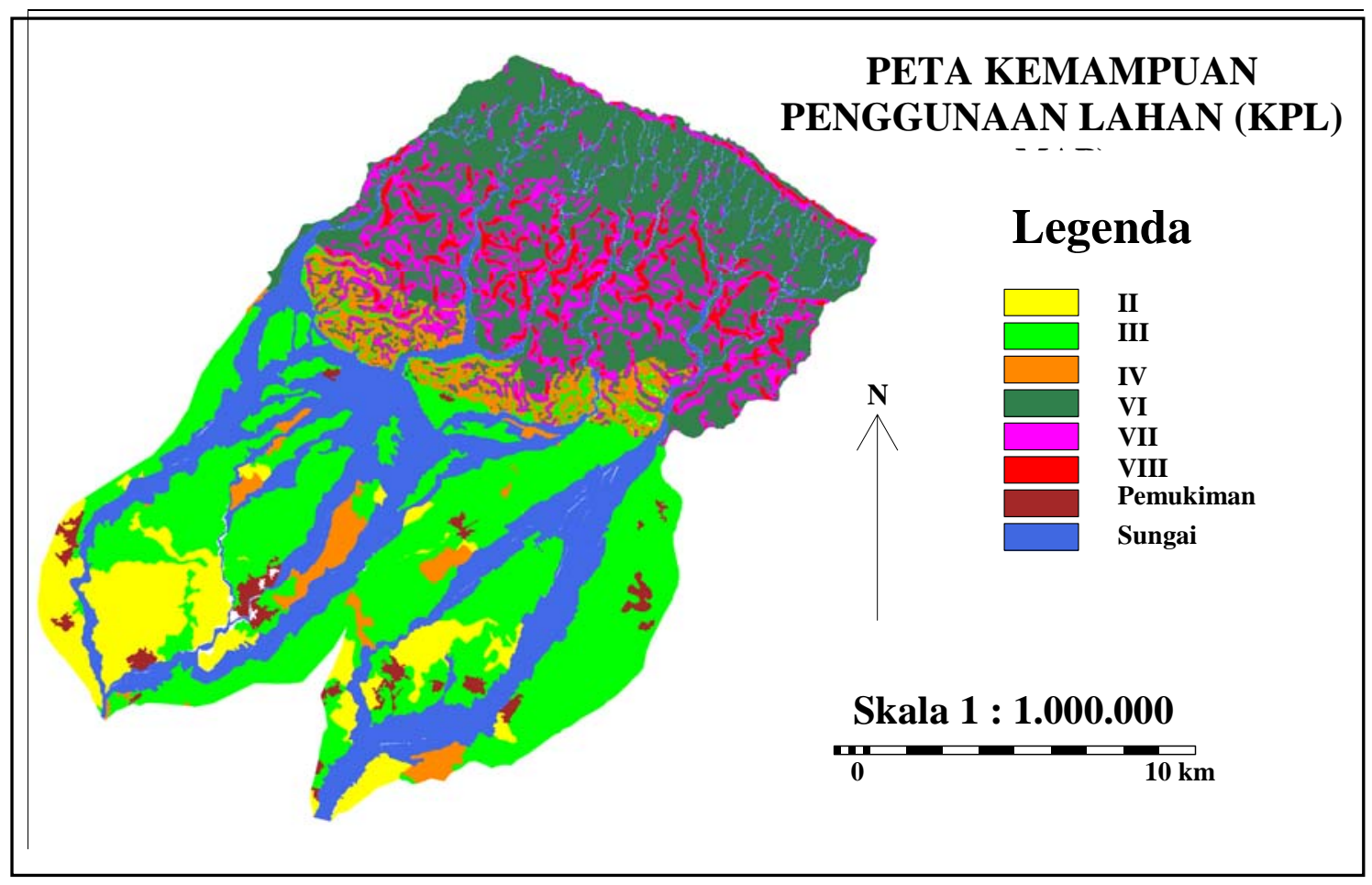

Gambar 3. Peta Kelas Kemampuan Penggunaan Lahan (KPL) 
tur yang memiliki ekonomi tinggi, sedangkan KPL VIII sebaiknya hanya untuk hutan lindung yang tidak boleh dijamah atau diproduksi.

\section{KESIMPULAN}

1. Penetapan KPL harus lebih teliti dan detil mengingat lahan dari hari ke hari semakin menyempit dan semakin mahal, untuk itu perlu ditetapkan rumus KPL dengan cara menghitung satu per satu parameter penentu yaitu KPL Tanah, KPL Erosi, dan KPL Lereng.

2. KPL Final selanjutnya dibuat matriks untuk mengkaitkan antara KPL dengan masung-masing Sub DAS dalam rangka memilih prioritas Sub DAS yaitu yang memiliki KPL dengan kelas rendah paling luas. Juga dihubungkan antar KPL dengan penggunaan lahan untuk memberikan rekomendasi pengembangan tanaman seefisien dan seefektif mung-kin.

3. Dari 11 Sub DAS yang menjadi prioritas untuk segera ditangani adalah Sub DAS Galr Rao karena sebagian besar lahan memiliki kelas KPL diatas VI, dan untuk kelas VIII termasuk paling luas diban- dingkan dengan Sub DAS yang lainnya.

4. Pada kelas KPL I - IV maka sebaiknya untuk tanaman pertanian antara lain tanaman gandum, tebu dan kebun mangga. Sedangkan KPL V - VIII untuk tanaman hutan rapat untuk mengurangi lahan yang kurang produk-tif terutama pada lahan semak belukar dan lahan bero.

5. Pengelolaan lahan tidak hanya memperhatikan kelas KPL tetapi dapat juga melihat sebaran bentuk lahan (landform), artinya pada bentuk lahan perbukitan (S) sebaiknya diupayakan untuk tanaman kehutanan, sedangkan pada daerah alluvial (A) dan daerah datar $(\mathrm{P})$ untuk tanaman pertanian.

6. KPL Tanah : semakin jelek kondisi lahan maka KPL mendekati VIII, sebaliknya semakin subur lahan akan mendekati kelas KPL I. KPL Erosi : pada lahan yang berpotensi erosi maka akan memiliki kelas KPL yang buruk yaitu mendekati VIII, sebaliknya yang tidak ada erosinya memiliki kelas KPL mendekati I. KPL Lereng: semakin curam lereng maka KPL akan mendekati ke kelas VIII, dan sebaliknya semakin datar lereng maka akan memiliki kelas KPL mendekati I.

\section{DAFTAR PUSTAKA}

Harjadi, B. 2004. "Karakteristik Sumberdaya Lahan sebagai Dasar Pengelolaan DAS di Sub DAS Merawu, DAS Serayu". Forum Geografi, Vol. 18, No. 2, Desember 2004. Hlm 91-114.

Harjadi, B. 2005. "Deteksi Kekritisan Lahan dengan Penginderaan Jauh dan Sistem Informasi Geografi (Studi Kasus Lahan Kritis Sub DAS Alang, Wonogiri)". Forum Geografi, Vol. 19, No. 1, Juli 2005. Hlm 1-15.

LAI, R. 1998. Soil erosion impact on agronomic productivity and environment quality. Critical Review, Plant Science, 17 : 319-464.

Morgan, R.P.C.., D.D.V. Morgan and H.J. Finney, 1984. A Predictive Model for The Assessment of Soil Erosion Risk. J. Agric. Engng. Res., 30, 245-253.

NZLRI, 2004. Brief Description of Land Use Capability Classes in New Zealand. Pertaining to Gisborne/East Coast. New Zealand Land Resources Inventory.

Wishmeier, W.D. and D.D. Smith, 1978. Predicting Rainfall Erosion Losses. A guide to conservation planning. USDA, Agriculture Handbook, No. 537. 
胥

\begin{tabular}{|c|c|c|c|c|c|c|c|c|c|c|c|}
\hline Ne & Bn.Lahaี่n & TX & KPL & $\mathrm{SD}$ & $\mathrm{SD}$ & KPL & BP & KPL & DR & KPL & KPL_F \\
\hline 1 & $\mathrm{~S} 11$ त్ & 1 & 1 & $\mathrm{~d}$ & $100-150$ & 2 & 20 & 3 & ex & 6 & 6 \\
\hline 2 & S12 总 & 1 & 1 & $\mathrm{~d}$ & $100-150$ & 2 & 20 & 3 & ex & 6 & 6 \\
\hline 3 & $\mathrm{~S} 21 \frac{0}{2}$ & $\mathrm{~L}$ & 2 & $\mathrm{~d}$ & $100-150$ & 2 & 30 & 3 & $\mathrm{ex}$ & 6 & 6 \\
\hline 4 & S22 胥 & $\mathrm{L}$ & 2 & $\mathrm{md}$ & $50-100$ & 3 & 30 & 3 & ex & 6 & 6 \\
\hline 5 & $\mathrm{~S} 23 \rightleftharpoons$ & $\mathrm{L}$ & 2 & $\mathrm{md}$ & $50-100$ & 3 & 30 & 3 & ex & 6 & 6 \\
\hline 6 & S31 胥 & $\mathrm{sl}$ & 2 & $\mathrm{vd}$ & $>150$ & 1 & 5 & 2 & $\mathrm{wl}$ & 1 & 2 \\
\hline 7 & S32 袁 & $\mathrm{sl}$ & 2 & $\mathrm{vd}$ & $>150$ & 1 & 40 & 3 & $\mathrm{wl}$ & 1 & 3 \\
\hline 8 & P11 d & ls / csl & 2 & $\mathrm{md}$ & $50-100$ & 3 & 5 & 2 & wl & 1 & 3 \\
\hline 9 & $\mathrm{P} 12_{\mathrm{F}}^{\mathrm{F}}$ & ls / csl & 2 & md & $50-100$ & 3 & 0 & 1 & wl & 1 & 3 \\
\hline 10 & P13 胥 & ls & 3 & $\mathrm{vd}$ & $>150$ & 1 & 10 & 2 & wl & 1 & 3 \\
\hline 11 & P21 E & $1 \mathrm{~s} / \mathrm{sl}$ & 1 & $\mathrm{vd}$ & $>150$ & 1 & 0 & 1 & wl & 1 & 1 \\
\hline 12 & P22 हृ & ls /sl & 1 & $\mathrm{vd}$ & $>150$ & 1 & 5 & 2 & $\mathrm{wl}$ & 1 & 2 \\
\hline 13 & P23 & ls & 3 & $\mathrm{~d}$ & $100-150$ & 2 & 0 & 1 & wl & 1 & 3 \\
\hline 14 & $\mathrm{~A} 11 \overline{\bar{\sigma}}$ & $\mathrm{sl} / 1$ & 1 & $\mathrm{vd}$ & $>150$ & 1 & 0 & 1 & wl & 1 & 1 \\
\hline 15 & $\mathrm{~A} 12$ & 1 & 1 & $\mathrm{vd}$ & $>150$ & 1 & 0 & 1 & wl & 1 & 1 \\
\hline 16 & A13 胥 & $1 \mathrm{~s} / \mathrm{sl}$ & 2 & $\mathrm{vd}$ & $>150$ & 1 & 0 & 1 & $\mathrm{md}$ & 2 & 2 \\
\hline 17 & A2 总 & n." & 1 & $\mathrm{vd}$ & $>150$ & 1 & 0 & 1 & wl & 1 & 1 \\
\hline 18 & 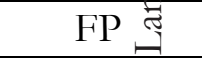 & Z & 3 & $\mathrm{vd}$ & $>150$ & 1 & 0 & 1 & wl & 1 & 3 \\
\hline 19 & STL & scl & 2 & vd & $>150$ & 1 & 10 & 2 & wl & 1 & 2 \\
\hline
\end{tabular}

